\title{
FENOMENA KEKUASAAN POLITIK DAN EKSISTENSI GENDER DALAM PERKEMBANGAN PENDIDIKAN
}

\author{
M. Zaki \\ Fakultas Ushuluddin dan Studi Agama \\ Universitas Islam Negeri Mataram
}

\begin{abstract}
The link between education and politics is understood by the community in two ways. First there are community groups who say that education is education and politics is political or between the two is separate. Secondly there are groups of people who argue that the two are interrelated. in a narrow sense, it needs to be remembered that politics in the narrow sense is interpreted as part of society as a politics of national life in which there is competition between certain groups or groups to fight for a desired position or position by justifying any means. Politics in education actually exists, an example; a vocational school principal who decides the policy of apprenticeship patterns for his students, whether that decision cannot be considered a political decision. Another example is the regulations concerning education that the government decides in the form of policies or guidelines are actually political decisions as well.
\end{abstract}

Key Word: Eksistensi Kekuasaan Politik, Gender, Perkembangan Pendidikan 


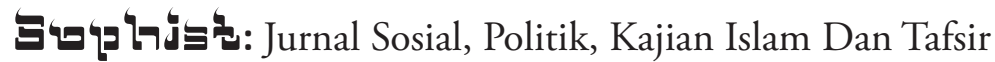

\section{A. Pendahuluan}

Setelah pelaksanaan otonomi pendidikan sebagai konsekuensi pelaksanaan otonomi daerah maka pengelolaan pendidikan tidak lagi sentralisasi dari pusat. Saat ini peran pemerintah daerah untuk memajukan pendidikannya menjadi sangat terbuka meskipun masingmasing daerah memiliki kesulitan baik masalah sumber daya manusia maupun minimnya dana pendidikan. Tantangan perkembangan dunia saat ini menuntut kemampuan sumber daya manusia yang tangguh dan memiliki kreativitas yang tinggi, tetapi bagaimana negara mampu menyiapkan SDM yang berkualitas tersebut masih mencari-cari pola hingga saat ini. mengemukakan dua fungsi besar negara, yaitu: mewujudkan kesejahteraan bagi rakyat banyak dan mempersatukan rakyat banyak tersebut dalam suatu wadah yang disebut negara. Kaitan antara pendidikan dan politik sangat erat bahkan selalu berhubungan sehingga dengan keadaan tersebut dapat kita ketahui bahwa politik negara sangat berperan menentukan arah perkembangan pendidikan di suatu negara. Tidak berlebihan kiranya bila banyak ahli yang berpendapat bahwa pendidikan sebagai salahsatu upaya atau sarana untuk melestarikan kekuasaan negara. Upaya menanamkan suatu prinsip, doktrin dan kesepakatan-kesepakatan negara melalui pendidikan dilakukan dengan cara yang tidak dapat ditelusur secara sekilas karena biasanya berada secara implisit dalam suatu materi pendidikan atau kurikulum sehingga secara tidak sadar sebenarnya masyarakat yang mengikuti dan memperoleh pendidikan telah mendukung pula tujuan khusus negara tersebut. ${ }^{1}$

Mengenyam pendidikan wajib bagi setiap warga negara Indonesia baik laki laki maupun perempuan, pendidikan tidak mengenal jenis gender, gender merupakan atribut yang melekat pada laki-laki dan perempuan yang dibentuk secara kultural. Gender membedakan struktur setiap aspek kehidupan sosial manusia berdasarkan perbedaan

1 Nurtanio Agus Purwanto, Pengaruh Politik Dalam Bidang Pendidikan, Jurnal Managemen Pendidikan Nomor 02/Th IV / Oktober /2008

2 Fenomena Kekuasaan Politik Dan Eksistensi Gender.... 
jenis kelamin. ${ }^{2}$ Isu gender adalah bagian dari persoalan sosial kemasyarakatan yang ada di Indonesia dalam dunia pendidikan dan agama. Salah satu indikator utama persoalan gender di kalangan ummat Islam adalah kesenjangan mencolok antara laki-laki dan perempuan. Dalam hal materi ajar, kitab-kitab paling populer yang diajarkan dalam pesantren, seperti kitab Uqudullujain, ${ }^{3}$ mengisyaratkan keberpihakan nyata kepada laki-laki dan ketidakseimbangan hak dan kewajiban antara suami dan istri. Kitab-kitab klasik ini dikarang oleh para penulis laki-laki dan dilestarikan di pesantren-pesantren yang pada gilirannya mengasumsikan maskulinisasi epistemologi pengetahuan agama. Sebagai konsep dalam analisis sosial, gender mengacu pada seperangkat sifat, peran, tanggung jawab, fungsi, hak dan perilaku yang melekat pada laki-laki dan perempuan sebagai bentukan budaya. ${ }^{4}$

Menurut Showalter, istilah gender mulai populer di awal tahun 1977, ketika sekelompok feminis London tidak lagi memakai isuisu lama seperti patriarchal atau sexist tetapi menggantinya dengan wacana gender (gender discourse). 5 Sebelum itu istilah "gender" sering

2 Pemela Sue Anderson, A Feminist Philosophy of Religion, (Blacwell:Blacwell Publisher, First Published, 1998), hlm.6.

3 Kitab ini adalah karya Muhammad Nawawi bin Umar bin `Arabi atau yang terkenal dengan nama Syekh Nawawi al Bantani, lahir di Tanara Serang Banten pada tahun 1813M/1230H dan wafat di Makkah pada tahun 1897/1914. Syekh Nawawi dalam kitab tersebut membahas relasi hubungan suami-istri, dengan memberikan tempat yang belum seimbang antara suami dan istri. Di satu sisi tampaknya ia akan memberikan tempat yang tinggi kepada perempuan dengan menekankan kewajiban menggauli istri dengan baik (makruf). Di sisi yang lain dia menempatkan istri sebagai "budak" milik suami yang dapat diperlakukan sesuai dengan kemauan pemiliknya. Ini tampaknya terjadi karena di satu sisi dia tersemangati oleh ajaran Islam yang ada dalam al Quran dan di sisi lain ia terkondisikan oleh budaya Timur Tengah yang paternalistik. Kitab Uqudullujain sangat populer, khususnya di kalangan pesantren, karena kitab ini dijadikan sebagai kitab rujukan bagi pasangan suami istri

4 Julia Cleves Mosse, Gender dan Pembangunan, (terjem), (Yogyakarta: Rifka WCC \&Pustaka Relajar, 1996), hlm.1-7

5 Patriarki telah menjadi fokus perdebatan dan mengalami berbagai perubahan arti dan interpretasi. Patriarki selain sebagai kontrol reproduksi biologis dan seksualitas, terutama dalam perkawinan monogami, juga sebagai kontrol terhadap kerja melalui pembagian kerja seksual dan sistim pewarisan. Lihat Ratna Saptari \& Brigitte Holzner, Perempuan, Kerja dan Perubahan Sosial, Sebuah pengantar Studi perempuan,(Jakarta, Kalyana Mitra, Grafitti, Jakarta, 199700), hlm.92. Begitu pula Muhadjir Darwin yang 
digunakan secara rancu dengan istilah "seks". Sosiolog Inggris, Ann Oakley, diakui sebagai orang pertama yang membedakan istilah gender dan seks. ${ }^{6}$

Masyarakat menciptakan sikap dan perilaku berdasarkan jenis kelamin, termasuk menentukan apa yang seharusnya membedakan perempuan dan laki-laki. Keyakinan tersebut diwariskan secara turun temurun melalui proses eksistensi baik dalam keluarga, masyarakat, lembaga pendidikan dan agama. Dalam lembaga lembaga yang terakhir itulah penelitian ini memusatkan perhatiannya. Gender juga dapat dipahami sebagai konsekuensi yang timbul akibat perbedaan anatomi biologis yang mendorong munculnya aspek-aspek kebudayaan. Sebagai istilah, gender digunakan belum terlalu lama.

Secara garis besar teori-teori gender dapat diklasifikasikan menjadi dua kelompok. Pertama adalah kelompok teori-teori nature yang mengatakan bahwa perbedaan peran laki-laki dan perempuan ditentukan oleh faktor biologis. Anatomi laki-laki, dengan sederet perbedaannya, dengan perempuan menjadi faktor utama dalam penentuan peran sosial kedua jenis kelamin. Laki-laki menjalankan peran-peran utama dalam masyarakat karena secara umum dianggap lebih potensial, lebih kuat, dan lebih produktif.

Organ reproduksi perempuan beserta fungsi yang diasosiasikan padanya, seperti hamil, melahirkan, dan menyusui, dianggap membatasi ruang dan gerak perempuan. Batasan ini tidak berlaku bagi laki-laki. Perbedaan inilah yang melahirkan pemisahan fungsi dan tangung jawab antara laki-laki dan perempuan. Termasuk dalam kelompok teori ini adalah teori fungsionalis struktural, teori sosiobiologis, dan psikoanalisa.

mengemukakan bahwa idiologi Patriarki merupakan salah satu variasi dari idiologi hegemoni yang membenarkan penguasaan suatu kelompok terhadap kelompok lainnya. Dominasi seperti ini terjadi berdasarkan perbedaan jenis kelamin, agama, ras, atau kelas ekonomi. Lihat Muhadjir Darwin dan Tukiran, Menggugat Budaya Patriarki,(Yogyakarta: PPK UGM-FF,2001), hlm.24.

6 Ratna Saptari \& Brigitte Holzner, Perempuan Kerja dan Perubahan Sosial, Sebuah pengantar Studi perempuan, (Jakarta, Kalyana Mitra, Grafitti, Jakarta, 1997), hlm. 89. 
Kedua, adalah kelompok teori-teori nurture yang melihat bahwa perbedaan karakter dan peran sosial antara laki-laki dan perempuan lebih ditentukan oleh faktor sosial-budaya. Perspektif ini menyimpulkan bahwa pembagian kerja antara laki-laki dan perempuan dalam masyarakat tidak ditentukan oleh faktor biologis, melainkan dikonstruksikan oleh budaya, yakni relasi kuasa (power relation) yang secara turun-temurun dipertahankan oleh laki-laki. Pandangan ini didukung oleh teori-teori konflik dan teori-teori feminis.

\section{B. Pembahasan}

\section{Pengaruh Kekuasaan Politik dan Eksitensi Gender Dalam Pendidikan}

Keterkaitan antara pendidikan dan politik dipahami oleh masyarakat dalam dua hal. Pertama ada kelompok masyarakat yang mengatakan bahwa pendidikan adalah pendidikan dan politik adalah politik atau antara keduanya terpisah. Kedua ada kelompok masyarakat yang berpendapat bahwa antara keduanya saling berkaitan. dalam arti sempit, perlu diingat bahwa politik dalam arti sempit diartikan sebagian masyarakat sebagai politik dalam percaturan kehidupan berbangsa dimana didalamnya terdapat persaingan antar kelompok atau golongan tertentu untuk memperebutkan suatu kedudukan atau posisi yang diinginkan dengan menghalalkan segala cara. Politik dalam bidang pendidikan sebenarnya ada, sebuah contoh; seorang kepala sekolah SMK yang memutuskan kebijakan tentang pola magang bagi siswa-siswanya, apakah keputusan itu tidak dapat dianggap sebagai sebuah keputusan politik. Contoh lain adalah peraturan-peraturan tentang pendidikan yang diputuskan pemerintah baik berupa kebijakan atau pedoman sebenarnya merupakan keputusan politik juga.

Hal itu beralasan karena sebelum sebuah peraturan tentang pendidikan diputuskan harus melalui pembahasan yang sangat sengit baik pada lembaga legislatif maupun eksekutif. Kita masih ingat bagaimana Undang-Undang No 20 tahun 2003 tentang sistem 
pendidikan nasional yang tertunda penetapannya untuk waktu yang tidak sebentar hanya karena ada salah satu pasal yang menjadi perdebatan. Di sana terjadi tarik menarik antara berbagai kelompok dan itu merupakan sesuatu yang lazim dalam dunia politik. ${ }^{7}$

Dari sedikit contoh diatas maka dapat kita simpulkan bahwa didalam dunia pendidikan politik juga berperan dan merupakan hal yang krusial bukan sekedar pelengkap saja. Hingga saat ini pandangan masyarakat masih menganggap bahwa hal pokok bagi kemajuan suatu bangsa adalah ekonomi dan politiknya. Hal itu tercermin dari pola pikir politikus kita yang selalu berorientasi pada dua bidang itu. Sangat jarang politikus yang memprioritaskan pada sektor pendidikan dalam agenda politiknya. Kondisi demikian juga terjadi dalam kehidupan berbangsa dan bernegara kita, prioritas pembangunan kita masih saja pada sector ekonomi, politik hankam, politik luar negeri dan belum pernah sampai pada wacana untuk memprioritaskan pada sector pendidikan. Hal demikian barang- kali juga dipicu oleh pemahaman bahwa pendidikan tidak secara langsung dapat diketahui hasilnya dan memerlukan biaya yang sangat besar sedangkan sektor lainnya bisa dengan cepat diketahui hasilnya.

Pendapat mana yang paling sesuai masih bisa diperdebatkan, pendapat yang pertama mengasumsikan bahwa mencampuradukkan antara pendidikan dan politik akan merugikan pendidikan karena didalam politik terdapat kondisi buruk atau jelek menurut pendapat kelompok masyarakat tertentu. Pendapat kedua cukup beralasan karena politik tidak dapat hanya dipahami

Pendidikan khususnya pendidikan formal disekolah merupakan tempat transfer pengetahuan tetapi juga sebagai tempat transfer nilai, nilai dalam hal ini sangat erat kaitannya dengan norma- norma dan segala sesuatu yang baik dimasyarakat. Saat ini banyak siswa sekolah yang samasekali tidak menaruh hormat pada guru maupun orangtua,

7 Nurtanio Agus Purwanto, Pengaruh Politi Dalam Bidang Pendidikan, Jurnal Managemen Pendidikan Nomor 02/Th IV / Oktober /2008 
hal itu bisa kita lihat dengan sopan santun mereka, jarang ada anak usia sekolah yang lewat didepan orangtua kemudian minta permisi karena mereka dengan cueknya melintas. Pada beberapa dasawarsa terdahulu dimasyarakat kita tatakrama sangat kuat dipegang, tidak ada yang berani membantah orangtua, guru, dan sebagainya tetapi kini orangtua disamakan hanya sebagai teman dan guru demikian pula, padahal harusnya mereka dihormati. Bagaimana pendidikan dapat menanamkan nilai - nilai yang baik juga memerlukan dukungansemua pihak, diyakini kemerosotan moral salah satunya karena pendidikan tetapi faktor masyarakat dan budaya yang berlaku juga menentukan. Banyak kendala dalam menanamkan nilai pada anak didik, antara lain:

a. Nilai-nilai masih dianggap hanya sebagai pelajaran semata, siswa belum menghayati secara benar bahwa nilai-nilai itu merupakan sebuah aktivitas yang melekat dalam dirinya bukan sekedar materi yang bisa dipelajari dan setelah itu dilupakan.

b. Dukungan masyarakat disekitar anak didik tinggal yang belum maksimal bahkan rendah, penanaman nilai bagi anak dilingkungan pasar atau terminal tentu lebih sulit dibandingkan dengan penanaman nilai bagi anak-anak di pedesaan yang belum terlalu tersentuh perubahan.

c. Guru kurang menguasai pola penanaman nilaiyang tepat, banyak guru-guru kita yang belum dapat menempatkan perbedaan individual dalam diri anak didiknya sebagai sebuah sarana untuk pembelajaran. Guru masih saja menyamaratakan segala yang diberikan kepada siswanya, memang untuk mengetahui karakter dan sifat anak masing-masing banyak kendalanya tetapi secara garis besar pasti guru mengetahui karena ia bertemu setiap hari dengan siswanya

Kaitan antara pendidikan dengan perwujudan kekuasaan sangat erat, dengan merujuk pada pandangan-pandangan Michel Foucault mengenai kaitan kekuasaan dan pendididkan. Proses eksistensi gender 
dalam lembaga agama melibatkan kekuasaan melalui sejumlah aspek sebagai berikut; mencakup pendisiplinan tindakan dan perilaku menurut sistem nilai tertentu; ${ }^{8}$ menuntut pengakuan dan penerimaan atas otoritas, nilai-nilai, ritus, simbol dan supremasi kebenaran budaya tertentu; ${ }^{9}$ melibatkan kontrol budaya serta; pelembagaan norma melalui simbolisasi figur-figur dan model-model kepercayaan tertentu. ${ }^{10}$ Lebih dari itu, eksistensi gender dapat dipandang sebagai salah satu strategi dan mekanisme yang dijalankan masyarakat dan komunitas untuk mempertahankan kekuasaan. ${ }^{11}$

Eksistensi gender mengedarkan pesan-pesan, wacana, nilai-nilai, norma-norma, kepercayaan dan model-model yang merepresentasikan kontruksi gender tertentu. Unsur-unsur tersebut termasuk dalam apa yang disebut Foucault dengan diskursus (discourse). Menurut Foucault, dalam diskursus inilah pengetahuan berpadu dengan kekuasaan. ${ }^{12}$ Dengan itu dapat dikatakan bahwa setiap ide, ajaran, pesan dan pengertian tentang laki-laki dan perempuan dalam masyarakat selalu mengandung perwujudan kekuasaan. Semua pengetahuan adalah konsekuensi dari hadirnya rejim kekuasaan tertentu. Pada saat yang sama kekuasaan beroperasi dengan terus-menerus menciptakan pengetahuan. Seperti dikatakan Foucault:

"Kekuasaan beroperasi terus menerus menciptakan pengetahuan dan begitu juga sebaliknya, pengetahuan mengasumsikan sebentuk implikasi dari kekuasaan. ..Pengetahuan dan kekuasaan terintegrasi satu sama lainnya dan tidak ada moment dalam suatu periode waktu di mana pengetahuan akan lepas dari ketergantungannya akan

8 Rosenthal, D. A. dan Feldman, S. S., "The acculturation of Chinese immigrants: effects on family functioning of length of residence in two cultural contexts", dalam Journal of Genetic Psychology, 1990, Vol. 4, hlm. 495-514.

9 Aziz Talbani dan Parven Hasanali, "Adolescent females between tradition and modernity: gender role socialization in South Asian immigrant culture", dalam Journal of Adolescence, 2000, Vol. 23, hlm. 616.

10 Hirst, J.S. and Thomas L. "Introduction: Playing for Real: Hindu Role Models, Religion and Gender”, dalam Hirst, J.S. and Thomas L.(ed), Playing for Real: Hindu Role Models, Religion and Gender, (Oxford: Oxford University Press, 2004), hlm. 2-3.

11 Aziz Talbani dan Parven Hasanali, op cit, hlm. 616

12 Michel Foucault, The History of Sexuality: An Introduction. terj. R. Hurley. (Harmondsworth: Penguin, 1978), hlm. 100.

8 Fenomena Kekuasaan Politik Dan Eksistensi Gender.... 


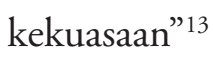

Kekuasaan memungkinkan bentuk-bentuk pengetahuan untuk membentuk realitas sosial yang mereka gambarkan dan analisis. Kekuasaan dan pengetahuan berimplikasi secara langsung satu sama lainnya. Hubungan kekuasaan antar pelaku sosial selalu membentuk sebuah arena pengetahuan. Demikian pula tidak ada pengatahuan, "..yang tidak secara bersamaan mengandaikan dan membentuk relasi kekuasaan." 14

Bagi Foucault, semua diskursus memiliki fungsi ideologis. Produksi pengetahuan selalu berjalin dengan rejim kekuasaan historis tertentu yang bersifat spesifik, karenanya setiap masyarakat menjalankan sistem kebenarannya sendiri yang memiliki fungsi regulasi dan normalisasi. ${ }^{15}$ Analisis terhadap diskursus-kekuasaan bukan ditujukan pada validitas atau nilai kebenaran, melainkan pada bagaimana sebuah diskursus beroparasi dalam kaitannya dengan struktur kekuasaan dalam sebuah institusi sosial. ${ }^{16}$ Seperti dinyatakan Foucault,

"..Masalahnya bukan menyusun garis pembeda antara diskursus yang termasuk dalam kategori ilmiah atau benar dan diskursus yang termasuk dalam kategori lain, tetapi melihat bagaimana efek historis dari kebenaran yang diproduksi dalam sebuah diskursus yang pada dirinya sendiri tidak benar atau tidak salah."17

Dalam perspektif feminis, makna "efek historis" dari kebenaran dipahami sebagai konsekuensi negatif dari produksi diskursus gender yang mapan bagi kehidupan perempuan.

13 Michel Foucault, Power/Knowledge: Selected interviews and Other Writings, 1972-1977, C. Gordon (ed). (Bringhton: Harvester, 1980) hlm. 52.

14 Michel Foucault, Discipline and Punish: the Birth of the Prison, Trans. A. Sheridan, (Harmondsworth: Peregrine, 1977) hlm. 27.

15 Lois McNay, Foucault and Feminism: Power, Gender and the Self, (Boston: Northeeastern University Press, 1992) hlm. 25.

.Ibid

17 Michel Foucault, Power/Knowledge: Selected interviews and Other Writings, 1972-1977, C. Gordon (ed). (Bringhton: Harvester, 1980) hlm. 118, dikutip juga dalam Lois McNay, op cit. 
Perhatian para ahli psikologi perkembangan sebagian besar dicurahkan pada eksistensi gender pada masa anak-anak dengan menitikberatkan pengaruh hubungan antara anak dengan orang tua terhadap identitas beserta perilaku gender anak-anak. Eksistensi diterangkan sebagai proses di mana anak-anak belajar mengenal identitas dan peran gender dalam keluarga dan masyarakat. ${ }^{18}$ Eksistensi bersifat kompleks, interaktif dan melibatkan sekurangnya tiga komponen yaitu: observasi, imitasi dan internalisasi. ${ }^{19}$ Anakanak pada awalnya mengamati tindakan dan perilaku orang yang lebih dewasa di sekitar mereka, terutama orang-orang tua terdekat. Selanjutnya mereka mengimitasi tindakan yang teramati tersebut dan belajar memberi penekanan berbeda terhadap perilaku gender yang dianggap "pantas" dan "tidak pantas". Oakley mengkaitkan imitasi dan internalisasi dengan identifikasi diri subjek bergender. Ia mengacu pada tendensi untuk mereproduksi tindakan-tindakan, sikap dan tanggapan mental baik yang terekspresi secara terbuka-nyata maupun melalui model-model simbolik. ${ }^{20}$

Meskipun demikian, kerangka eksistensi gender juga digunakan untuk memahami proses identifikasi stereotipe gender yang terjadi pada remaja dan individu yang lebih dewasa. ${ }^{21}$ Sepanjang masa perkembangannya berlanjut, individu berada diluar ikatan keluarga

18 Carol Nagy Jacklin, "Female and Male: Issues of Gender", dalam American Psychologist, 1989, Vol. 44. No. 2, hlm. 131 dan Robert C. Johnson, "The black family and black community development", dalam Journal of Black Psychology, 1981, Vol. 8, hlm. 25.

19 A. Walker, "Conceptual perspectives on gender and family caregiving". dalam J. Dwyer, \& R. Coward (Eds.), Gender, families, and elder care (Newbury Park, CA: SAGE, 1992) hlm. 35.

20 Ann Oakley, Sex, Gender, and Society (London: Maurice Temple Smith, 1972), hlm. 179.

21 Dua contoh studi yang menerapkan kerangka sosialisasi gender untuk masa perkembangan lebih lanjut adalah: Aziz Talbani dan Parven Hasanali, "Adolescent females between tradition and modernity: gender role socialization in South Asian immigrant culture”, dalam Journal of Adolescence, 2000, Vol. 23, hlm. 615-627 dan; Carrie Paechter, "Learning Masculinities and Feminities: Power/Knowledge and Legitimate Peripheral Participation", dalam Women's Studies International Forum, 2003 Vol. 26, No. 6, hlm. 541 $-552$. 
dan memasuki komunitas yang lebih luas di mana proses eksistensi berlanjut, terutama dalam lembaga pendidikan dan agama. Sepanjang periode tersebut, peran-peran gender terinternalisasi sebagai bagian dari kepribadian dan identitas individu. ${ }^{22}$ Eksistensi di sini secara khusus berfungsi menyiapkan individu untuk memasuki kehidupan dalam masyarakat yang lebih dewasa. Pada tahap ini, eksistensi gender menghasilkan sistem referensi yang lebih tegas mengenai perilakuperilaku yang dianjurkan dan yang dilarang. ${ }^{23}$ Perilaku yang dianjurkan adalah perilaku yang didorong dan diutamakan oleh masyarakat sementara perilaku yang dilarang adalah perilaku yang dianggap tabu oleh masyarakat.

Dengan kerangka eksistensi, lembaga pendidikan dapat dipandang sebagai lembaga sosial di mana proses eksistensi gender pada tahap paska anak-anak berlangsung. Dalam proses ini, diedarkan seperangkat wacana dan ide-ide yang menyediakan pengertian bagi santri mengenai identitas mereka sebagai laki-laki atau perempuan. Lebih dari itu, proses tersebut juga memproduksi pesan-pesan, norma-norma, tuntutan, tata aturan dan simbol-simbol yang membentuk sistem referensi bagi perilaku anak didik berdasarkan gender mereka.

Agen yang berperan dalam eksistensi gender adalah orangorang atau kelompok sosial yang menyediakan, atau mengedarkan, informasi-informasi kunci mengenai nilai-nilai, perilaku dan pesanpesan gender. Pada masa anak-anak, informasi ini dibutuhkan sebagai media imitasi dan identifikasi gender mereka. Pada tahap selanjutnya menuju kedewasaan, informasi-informasi merupakan referensi mengenai bagaimana individu belajar menjadi bagian yang absah dari sebuah komunitas dan berpartisipasi di dalamnya sebagai individu yang mengemban simbol-simbol feminin atau maskulin.

22 Ann Oakley, op cit. hlm. 186.

23 Montgomery, "Gender differences in patterns of child-parent caregiving relationships", dalam J. Dwyer, dan R. Coward (Eds.), Gender, families, and elder care, (Newbury Park, CA: SAGE, 1992) hlm. 65-83. 
Peran agen dalam membentuk eksistensi gender tidak berdiri otonom satu sama lainnya. Pesan-pesan gender yang mereka sampaikan juga seringkali tidak konsistem dan berkontradiksi. ${ }^{24}$ Pada saat yang sama, mereka juga mempresentasikan perbedaan level kekuasaan. Proses eksistensi gender, karenanya, dapat dipahami sebagai sebuah kontestasi di mana wacana, ide-ide dan pesan-pesan gender yang berbeda saling bergesekan. Salah satu implikasi dari kondisi demikian adalah dihasilkannya ketidakseimbangan kekuasaan di mana salah satu kelompok lebih diuntungkan daripada kelompok yang lain. Dalam konteks lembaga pendidikan, fenomena eksistensi gender dapat dipahami sebagai arena kontestasi antara para agen eksistensi yang membawa pesan-pesan dan wacana gender yang berbeda atau bahkan berlawanan. Kontestasi ini dapat menciptakan ketidakseimbangan kekuasaan antara anggota masyarakat.

Eksistensi gender dalam masyarakat dikategorikan dalam dua model yaitu strong model dan reflexive model Pembedaan ini mengikuti kategori yang diciptakan oleh Brittan dan Myrnard. Pada strong model, para santri dipandang sebagai subjek dapat dibentuk, diproduksi dan ditentukan oleh kekuatan sosial di luarnya dan kekuatan agen-agen eksistensi. Sementara menurut reflexive model berlangsung dua proses. Pertama, subjek dipandang terlibat secara aktif dalam eksistensi, bukan sekedar penerima pasif, dan memiliki kapasitas untuk memilih, menginterpretasi, memodifikasi dan menentukan apakah akan memilih atau menolak pesan-pesan sosial-kultural. Kedua, eksistensi gender berlangsung sebagai sebuah proses negosiasi, bersifat situasional dan mempunyai makna yang lebih kontekstual.

Persoalan tentang bagaimana sesungguhnya proses eksistensi gender berlangsung telah lama menjadi tema besar khususnya dalam bidang psikologi perkembangan. Sosialisai gender yang dialami lakilaki dan perempuan terjadi sejak masa bayi lahir. Proses ini terjadi melalui pemberian atribut-atribut terhadap bayi yang secara sosial

24 Linda L. Lindsey, op cit. hlm. 61. 
mengidentifikasi jenis kelaminnya. ${ }^{25}$ Terdapat empat teori besar yang menjelaskan eksistensi gender pada masyarakat, atau keluarga sebagaimana sebagian besar perhatian para peneliti tercurah, yakni psychoanalytic, social learning, cognitive-developmental dan gender schema. ${ }^{26}$

Teori psychoanalytic atau psychoanalytic theory of gender mengemukakan pengalaman pada fase kanak-kanak yang krusial. Pengalaman ini mempengaruhi kepribadian dan psikologi anak, sehingga tanpa disadari individu akan melakukan apa yang pernah mereka alami ketika masih kanak-kanak. Kecenderungan ini disebut sebagai unsounscious (perilaku yang tidak disadarinya) dan hal ini bersifat permanen. Salah satu pandangan pokok teori ini adalah bahwa anak perempuan lebih bersifat komunal atau lebih mampu beradaptasi dan lebih mudah bereksistensi dengan masyarakat. Sementara anak laki-laki lebih bersifat agentic, individual dan acuh tak acuh terhadap lingkungan. Anak-anak juga mengidentifikasi persamaan sex. Bila anak laki-laki mengidentifikasi pada ayah, maka anak perempuan mengidentifikasikan dirinya kepada ibu.

Teori social learning memberi tekanan pada kemampuan belajar anak-anak terhadap lingkungan di sekitarnya, khususnya keluarga. Dalam teori ini, lingkungan merupakan aspek yang sangat penting dalam mengembangkan identitas dan perilaku gender pada anak-anak. Mereka belajar memainkan peran yang dibawanya melalui perlakuan, penghargaan, dan hukuman yang diterima secara berbeda antara anak laki-laki dan perempuan. Dalam pandangan teori ini ditekankan bahwa perkembangan gender anak-anak dan remaja muncul sebagai hasil pengamatan dan imitasi terhadap perilaku gender orang lain, seperti orang tua, orang dewasa lain, teman sebaya, lingkungan sekitar dan media massa. Anak-anak memiliki kemampuan untuk secara

25 Yoyce McCarl Nielsen, Sex and Gender in Society, Perspectives on Stratification, edisi kedua, (University of Colorado, Wafeland Press Inc. 1990), hlm. 169.

26 Susan A. Basow, Gender Streotypes and Roles, edisi ke-3, (California: Pacific Grove, 1992), hlm. 118-126 dan Linda L. Lindsey, Gender Roles: A Sociological Perspective, edisi ke 4 (New Jersey: Pearson education, Inc., Upper Saddle River, 2005), hlm. 56-59. 
bebas memilih model-model yang memperlihatkan perilaku maskulin dan feminin. Orang tua sering menggunakan hadiah (rewards) dan hukuman (punishment) untuk mengajarkan anak perempuan menjadi feminin dan anak laki-laki menjadi maskulin.

Sedangkan pandangan utama teori cognitive-development adalah bahwa remaja membentuk dunia gender mereka sendiri secara aktif. Bentuk gender anak-anak muncul setelah mereka mengembangkan suatu konsep tentang gender pada saat mereka memahami diri mereka sebagai laki-laki atau sebagai perempuan secara konsisten. Berdasar teori Kohlberg, anak laki-laki, misalnya, akan menjadi laki-laki tanpa peduli apakah ia mengenakan pakaian-pakaian yang menunjukkan identitas gender perempuan atau sebaliknya.

Pendekatan keempat, gender schema, dianggap lebih maju dan menjanjikan dari pada ketiga pendekatan sebelumnya. Dalam teori ini mendasarkan pada kemampuan anak-anak dalam menyusun skema dalam pemikiran mereka yang berguna untuk memahami dunia di luar mereka, menginterpretasi, serta mengolah informasi-informasi baru yang mereka terima. Teori ini mengasumsikan bahwa identitas gender anak-anak diciptakan terlebih dahulu yang kemudian diikuti oleh perkembanan skema secara lebih kompleks dan lebih khusus pada komunitas di mana anak berkembang. Pada masyarakat di mana perbedaan gender sangat rigid, anak-anak mengembangkan skema gender secara lebih kompleks dan rigid mengikuti informasi yang mereka terima dari kultur bersangkutan.

Terkait dengan persoalan eksistensi gender, maka peran tokoh memegang peranan yang sangat penting dalam meneksistensikan ide-ide kesetaraan gender, apabila mereka memiliki kesempatan dan otoritas yang lebih signifikan. Diharapkan, peluang terciptanya relasi gender yang seimbang dan non-diskriminatif dalam lingkungan masyarakat akan semakin terbuka.

\section{Penutup}

14 Fenomena Kekuasaan Politik Dan Eksistensi Gender.... 
Dengan kerangka eksistensi, lembaga pendidikan dapat dipandang sebagai lembaga sosial di mana proses eksistensi gender pada tahap paska anak-anak berlangsung. Dalam proses ini terjadilah seperangkat wacana dan ide-ide yang menyediakan pengertian bagi peserta didik mengenai identitas mereka sebagai laki-laki atau perempuan. Lebih dari itu, proses tersebut juga memproduksi pesanpesan, norma-norma, tuntutan, tata aturan dan simbol-simbol yang membentuk sistem referensi bagi perilaku anak didik berdasarkan gender mereka.

Pihak-pihak yang berperan dalam eksistensi gender adalah orangorang atau kelompok sosial yang menyediakan, atau mengedarkan, informasi-informasi kunci mengenai nilai-nilai, perilaku dan pesanpesan gender. Pada masa anak-anak, informasi ini dibutuhkan sebagai media imitasi dan identifikasi gender mereka. Pada tahap selanjutnya menuju kedewasaan, informasi-informasi merupakan referensi mengenai bagaimana individu belajar menjadi bagian yang absah dari sebuah komunitas dan berpartisipasi di dalamnya sebagai individu yang mengemban simbol-simbol feminin atau maskulin. 


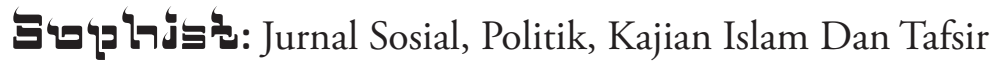

\section{Daftar Pustaka}

Ali Imron, Kebijaksanaan Pendidikan di Indonesia Yogyakarta: Bumi Aksara, 1998 H.A.R. Tilaar. Kekuasaan dan Pendidikan. Magelang: Indonesi Tera, 2003

Mansour fakih. Sesat Pikir Teori Pembangunan dan Globalisasi Jogjakarta:Insist/Pustaka Pelajar, 2001

Abdullah, Amin, Studi Agama: Normativitas atau Historisitas?, Yogyakarta: Pustaka Pelajar, 1996.

, "Rekonstruksi Metodologi Studi Agama dalam Masyarakat Multikultural dan Multirelijius", Pidato Pengukuhan Guru Besar Filsafat, IAIN Sunan Kalijaga Yogyakarta, 3 Mei 2000.

Abu Zayd, Nasr Hamid, Dekonstruksi Gender: Kritik Wacana Perempuan dalam Islam, terj. Nur Ikhwan dkk, Yogyakarta: PSW UIN-Samha, 2003.

Agus Purwanto, Nurtanio, Pengaruh Politik Dalam Bidang Pendidikan, Jurnal Managemen Pendidikan Nomor 02/Th IV / Oktober /2008

Ali Engineer, Asghar, The rights of Women in Islam, New York: St . Martin's Press, 1992.

Arivia, Gadis, Filsafat Berperspektif Feminis, Jakarta: Yayasan Jurnal Perempuan, 2003.

Basow, Susan A. Gender Stereotypes and Role, California: Cole Publishing Company, 1980.

Bruce Joyce \& Marsha Weil, Models of Teaching, Prentice-Hall, New Jersey: Englewood Cliffs, 1980.

Fakih, Mansour, Analisis Gender dan Transformasi Sosial, Yogyakarta: Pustaka Pelajar, 1996.

16 Fenomena Kekuasaan Politik Dan Eksistensi Gender.... 
Frieze H, Irene, (ed), Women and Sex Roles, A. Social Psychological Perspective, W.W.Norton \& Company, Inc, 1978.

Freud, Sigmund, Psikoanalisis Sigmund Freud. terj. Alimandan Yogyakarta: Ikin Teralitera, 2002.

Foucault, Michel, The History of Sexuality: An Introduction. terj. R. Hurley. Harmondsworth: Penguin, 1978.

, Power/Knowledge: Selected interviews and Other Writings, 1972-1977, C. Gordon (ed). Bringhton: Harvester, 1980

, Discipline and Punish: the Birth of the Prison, (terj) A. Sheridan, Harmondsworth: Peregrine, 1977.

Gloria Bowles dan Renate Duelli Klein, Theories of Women's Sudies, London: Routledgge \& Kegan Paul, t.t

Harvey et all, Contemporary Issues in Educational Psychology, Boston: Michigan State University, 1974.

Hekman, Susan. Gender and Knowladge :Elements of Postmodern Feminism, London: Polity Press, 1990

Hidayat, Rahmad, Ilmu yang Seksis, Yogyakarta: Jendela, 2004. 